\title{
Mosasaur remains from the Upper Cretaceous Izumi Group of southwest Japan
}

\section{Tanimoto}

Higashi 3-249, Yurigaoka, Nabari, Mie 518-0473, Japan. Email: tanimo28@e-net.or.jp

Manuscript received: November 2004; accepted: February 2005

\begin{abstract}
Until recently, mosasaur remains from the Izumi Group (Upper Cretaceous) in southwest Japan comprised only scattered finds; now a richer material is available. From the upper Campanian Hiketa Formation in Kagawa Prefecture, Kourisodon sp. has just been recorded, on the basis of portions of skull and mandible which has small and laterally compressed teeth. A few teeth of the same or similar type have previously been described from the Maastrichtian Mutsuo Formation in 0saka Prefecture. A report of Mosasaurus sp. A, which resembles M. missouriensis and M. dekayi, is based on some cranial and mandible remains, inclusive of numerous teeth and a few well-preserved cervical and two incomplete dorsal vertebrae, from the Maastrichtian Mutsuo Formation in 0saka Prefecture. A slender tooth of Mosasaurus sp. from the Mutsuo Formation has since been reassigned to Platecarpus (Plioplatecarpinae); yet, this may indeed by a species of Mosasaurus, here listed as Mosasaurus sp. B. To date, smaller specimens of mosasaurids have been shown to be abundant in the Izumi Group, which suggests two possible explanations. Either most of these represent juveniles, or smaller-sized, Kourisodon-like animals flourished here. Finds of Kourisodon sp. from the upper Campanian Hiketa Formation and the Maastrichtian Mutsuo Formation suggests the second explanation is the more likely one.
\end{abstract}

Keywords: mosasaurs, Upper Cretaceous, Izumi Group, southwest Japan

\section{Introduction}

The first report of mosasasurs from Japan, and from Asia for that matter, is that by Obata et al. (1972) from Hokkaido (northern Japan). Subsequently, Suzuki (1985a) recorded material from Hokkaido, while Kawakami et al. (1985) described two mosasaur teeth from Iwate Prefecture (NE Japan). Suzuki (1985b) erected a new species of mosasaur, Mosasaurus hobetsuensis, from the lower Maastrichtian of Hobetsu (Hokkaido), which represents the first description of a new mosasaur taxon from Japan. Later, an additional new species, also from Hobetsu, was introduced, Mosasaurus prismaticus, of late Campanian-Maastrichtian age (Sakurai et al., 1999).

The first record of mosasaur fossils from southwest Japan is that by Iwaki \& Maeda (1989), who illustrated a tooth from Awaji Island, labelled merely as a 'marine reptile tooth', but did not provide any description. Other material from this region was figured in a guide to Cretaceous fossils of the Izumi
Mountains (Geological Club of Kinki, 1991). Here, photographs illustrating two aspects of a mosasaur tooth are included, but no description was given; the specimen is from the (?mid-) Maastrichtian Kokawa Formation of Wakayama Prefecture.

In 0saka Prefecture, situated west of Wakayama Prefecture, there are no early records of mosasaur finds. However, to date this is the most prolific source of mosasaur fossils from the Izumi Group. The first record of Izumi Group mosasaurs is that by Tanimoto (1993). Later, Tanimoto et al. (1994) presented a slightly more detailed report on relatively well-preserved material from the Maastrichtian of Sobura (Kaizuka City). Subsequent to this, numerous finds have been made, and lots of reports have been published - these are here reviewed.

\section{Geological setting}

The Upper Cretaceous Izumi Group constitutes a thick sequence of marine deposits, composed mainly of alternating beds of 
conglomerate, sandstone and mudstone of turbidite facies. It is distributed in a narrow belt along the Median Tectonic Line, over an extent of about $300 \mathrm{~km}$, from the west of Shikoku Island eastwards of the Izumi Mountains (Honshu Island), across northern Shikoku Island and occupying the southern half of Awaji Island (Morozumi, 1985).

Generally speaking, this forms a synclinal structure with an easterly plunge of fold axes. The age of the strata becomes younger towards the east from western Shikoku Island (Campanian), across Awaji Island (Campanian and Maastrichtian) to the Izumi Mountain Range (Maastrichtian) (Itihara et al., 1986). Intra-Japanese correlation by means of ammonite faunas and international correlation and age assignment by Morozumi (1985) are referred to for a detailed analysis of the age of the Izumi Group.

\section{Mosasaur remains of the Izumi Group}

Below, finds of mosasaurs are listed proceeding from west to east, i.e. basically, from older to younger, within the Izumi Group, with some exceptions.

Shikoku Island - Only a single mosasaur fossil is known from the upper Campanian Hiketa Formation (stratigraphic research by Tsujino, 2004) at Kanewari (Sanuki City, Kagawa Prefecture). This record involves an anterior portion of skull and lower jaws of Kourisodon sp. (Tanimoto \& Kanazawa, 2001; Tanimoto et al., 2004). This is a small mosasaurid with laterally compressed teeth; the same or similar type of teeth are also known from the Maastrichtian of Osaka Prefecture (Tanimoto \& Date, 2000a; Tanimoto et al., 1998, 2001). When Nicholls \& Meckert (2002) described Kourisodon puntledgensis from the upper Santonian of Canada, they noted that the teeth of $K$. puntledgensis are closely similar to those from the Maastrichtian of 0saka Prefecture described by Tanimoto et al. (1998). Both have similar prows on the dentary as well, but the Kanewari specimen has longer maxillary teeth with clearer facets than does $K$. puntledgensis. The latter feature resembles Mosasaurus prismaticus from Hokkaido (Sakurai et al., 1999). In order to determine the relationship between these animals additional material is needed.

Awaji Island - The Seidan Formation is considered to be of late Campanian age. At Nagata (Minamiawaji City), a vertebra was collected from this unit - this was briefly described by Tanimoto \& Miyamoto (1996). Because the specimen is incomplete, it does not yield detailed information.

The largest portion of the Izumi Group in this island is of early Maastrichtian age. Articulated distal portions of a mosasaurine caudal vertebral column, showing fused haemal arches, has been recorded from the Shimonada Formation at Nadaokawa (Minamiawaji City, Hyogo Prefecture) by Tanimoto \& Kikyo (2001b). Another remarkable find are three large,

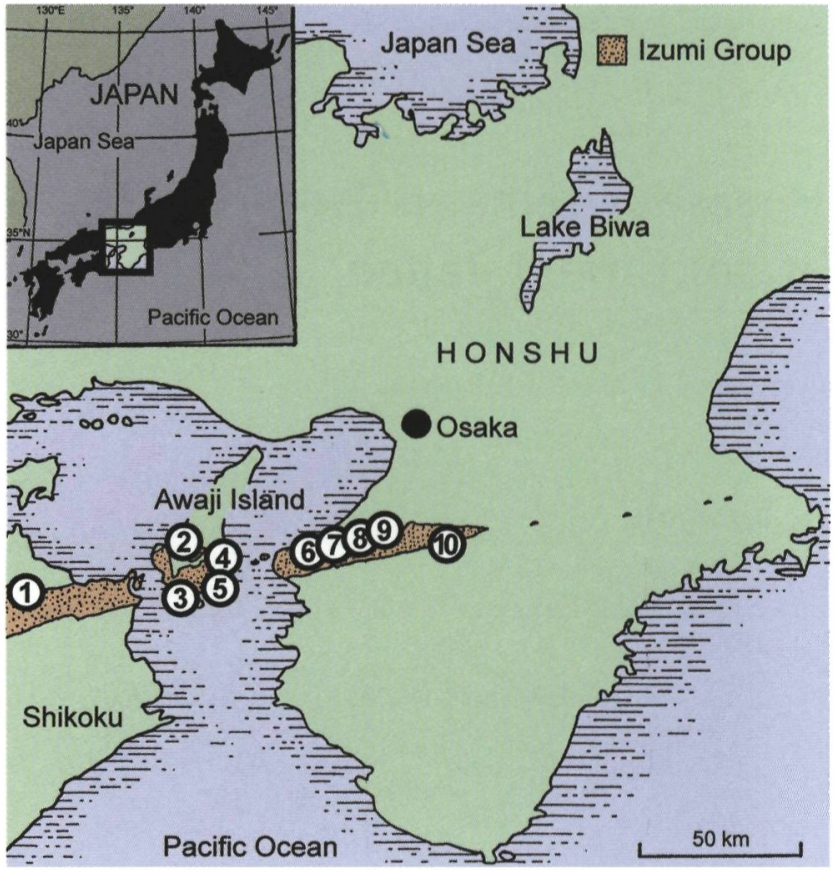

Fig. 1. Distribution of the Izumi Group (especially the eastern parts) and the localities yielding mosasaur fossils. Locality 1: Kanewari, Sanuki City, Kagawa Prefecture. Locality 2: Nagata, Minamiawaji City, Hyogo Prefecture. Locality 3: Nadaokawa, Minamiawaji City, Hyogo Prefecture. Locality 4: Akeda, Sumoto City, Hyogo Prefecture. Locality 5: Mitsugawa, Sumoto City, Hyogo Prefecture. Locality 6: Hakotsukuri, Hannan City, Osaka Prefecture. Locality 7: Showaike, Sennan City, Osaka Prefecture. Locality 8: Takinoike, Izumisano City, Osaka Prefecture. Locality 9: Sobura, Kaizuka City, Osaka Prefecture. Locality 10: Hashiramoto, Hashimoto City, Wakayama Prefecture.

semi-articulated lumbar vertebrae from the Kita-ama Formation at Akeda (Sumoto City, Hyogo Prefecture; see Tanimoto \& Kishimoto, 2002). This is the largest mosasaur individual to have been described from the Izumi Group to date. Preservation is not particularly good and identification at the subfamily level difficult; the total length of the animal is estimated to have been around ten metres. The same unit has also yielded a tooth at Mitsugawa (Sumoto City), illustrated as 'Marine reptile tooth' by Iwaki \& Maeda (1989).

Izumi Mountains of Honshu Island - The age of mosasaur material from this island is considered to be Maastrichtian. The westernmost locality that has yielded specimens is Hakotsukuri (Hannan City, Osaka Prefecture), exposing the Shintachi Formation. A few isolated remains are known from here, but no detailed descriptions have appeared in print yet (see abstracts: Tanimoto, 1993; Tanimoto et al., 1995). One of these specimens, a caudal vertebra with fused chevron (hence assignable to the Mosasaurinae) and transverse process, will be published soon (Tanimoto et al., in press).

A single, slender tooth from Showaike (Sennan City, Osaka Prefecture; Mutsuo Formation) constitutes an interesting record. Tanimoto \& Nunoya (2000) regarded it as Mosasaurus sp., 


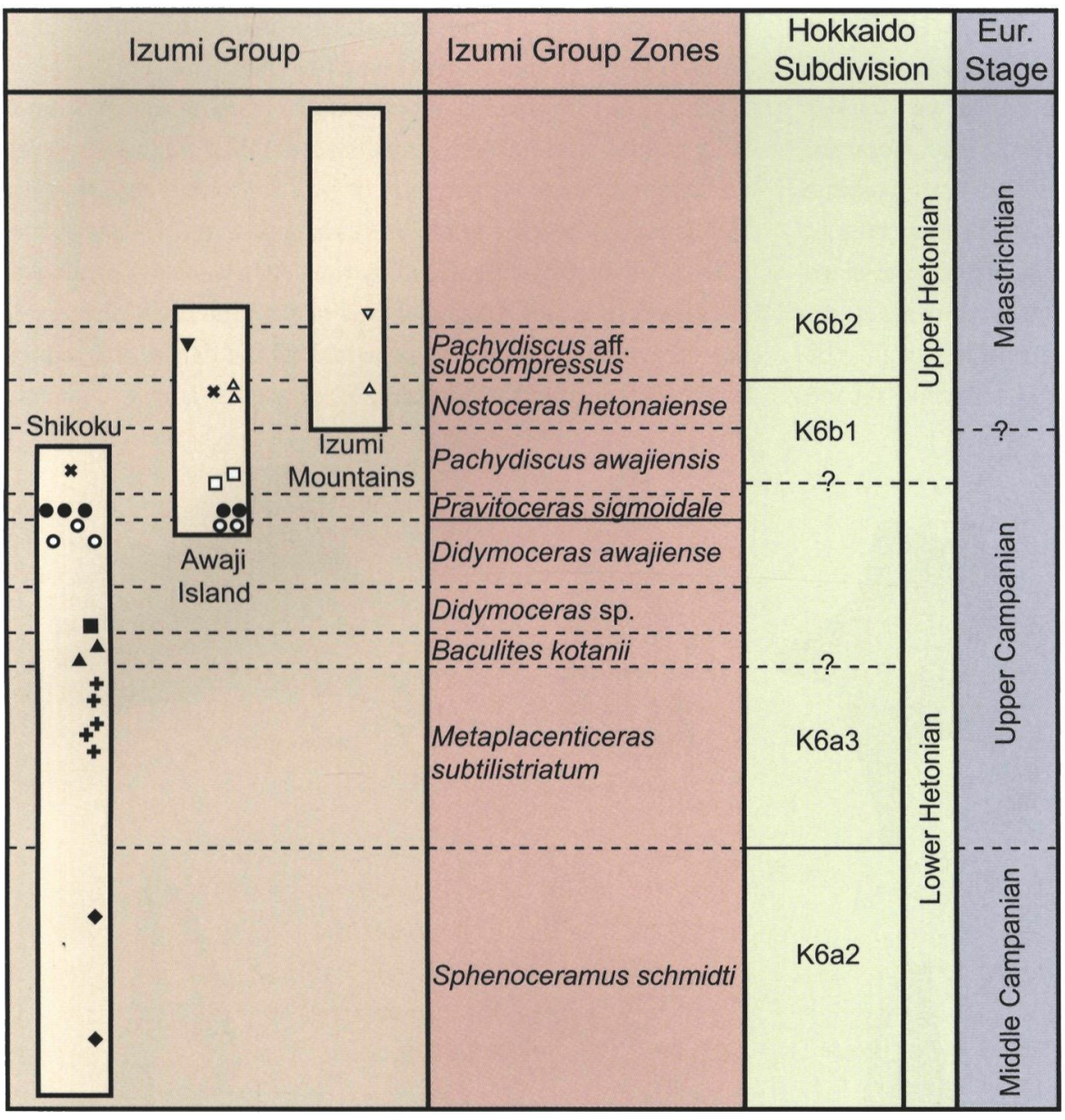

Inoceramids

* Inoceramus shikotanensis

- Sphenoceramus schmidti

Ammonites

$\checkmark$ Pachydiscus aff. flexuosus

- Pachydiscus aff. subcompressus

$\triangle$ Nostoceras hetonaiense

- Pachydiscus awajiensis

- Pravitoceras sigmoidale

- Didymoceras awajiense

- Didymoceras sp.

- Baculites kotanii

+ Metaplacenticeras subtilistriatum

Fig. 2. Biostratigraphic correlation of the Izumi Group (from Morozumi, 1985).

while Tanimoto \& Nunoya (2003) reassigned it to the genus Platecarpus. In fact, it is similar to Mosasaurus conodon and may represent a new species of Mosasaurus. It is here listed as Mosasaurus sp. B.

Takinoike (Izumisano City, Osaka Prefecture; Mutsuo Formation) constitutes a prolific locality of fossil marine vertebrate teeth, mainly sharks, but also some mosasaur teeth are known from here, representing the small and laterally compressed Kourisodon-like type (see Tanimoto et al., 2001).

Mosasaur fossils from the Mutsuo Formation at Sobura (Kaizuka City, Osaka Prefecture) are remarkable as far as quality and number of specimens are concerned. Here, the first Kourisodon-like teeth were collected (Tanimoto et al., 1998). A few small cervical vertebrae and a phalange discovered here have been described as possible juveniles of Mosasaurus sp. (Tanimoto \& Date, 2000b; Tanimoto \& Ueno, 2000). A comparison with finds of the small mosasaurine Kourisodon from the Izumi Group suggest that these fossils also belong to Kourisodon. A posterior dorsal vertebra discovered at this locality has recently been published as Mosasauridae gen. et sp. indet. by Takata (2004). In view of its small size, this may be assignable to Kourisodon or a similar-sized mosasaurid as well.

A record of Mosasaurus sp. A is based on a few cranial and mandible remains, inclusive of numerous teeth and a number of well preserved cervical and two incomplete dorsal vertebrae, is also from this locality. Its teeth, which are D shaped in cross section and have prisms on the crown and serration on cutting edges, are more robust than Mosasaurus sp. B of Showaike and resemble $M$. missouriensis or $M$. dekayi. Recently a well preserved dentary bone of this species (may be the same individual) was also found and described. These remains document a medium-sized animal, i.e. of a total estimated length of $6 \mathrm{~m}$ or more (Tanimoto, 1993; Tanimoto, 1997a; Tanimoto et al., 1994; Tanimoto et al., 2004; Tanimoto \& Yokoi, 2005).

The easternmost locality that has yielded mosasaur fossils from the Izumi Group is Hashiramoto (Hashimoto City, Wakayama Prefecture), exposing the Kokawa Formation, of mid-Maastrichtian or younger age (Tanimoto \& Takata, 2002). The sole mosasaur tooth (Mosasauridae gen. et sp. indet., but possibly belonging to the Mosasaurinae) was found about twenty years ago. Unfortunately, this specimen has not yet been described; photographs may be found in Geological Club of Kinki (1991), Tanimoto (1997b) and Ohara (2004).

\section{Discussion}

The above-mentioned specimens all represent the Mosasaurinae or Mosasauridae gen. et sp. indet. Only two definite records of the genus Mosasaurus from the Izumi Group are known to date; one of them being a massive tooth (from Sobura), the 
other one a slender type of tooth (from Showaike). The former is here referred to as Mosasaurus sp. A, the latter as Mosasaurus sp. B. The small mosasaurine Kourisodon sp. is well known from the Izumi Group. Abundant material of small mosasaur fossils from this unit suggests that there are two possible explanations to account for this. First, most material may in fact constitute juvenile individuals, and secondly, smaller-sized mosasaurids may have flourished here. Finds of Kourisodon sp. from the upper Campanian Hiketa Formation and the Maastrichtian Mutsuo Formation suggest that the second explanation may be the more likely one, although in some cases these may indeed represent juveniles.

The Kanewari specimen, of late Campanian age, is known from cranial material which enables a detailed comparison with Canadian Kourisodon, which is of late Santonian age, whereas the Japanese species is of late Campanian and Maastrichtian date. A few features displayed by the Japanese material suggest it represents a new species of this genus. The Izumi Group sea hosted a number of more ancient such as the fish Gillicus, which flourished during the Santonian, of which a near-complete
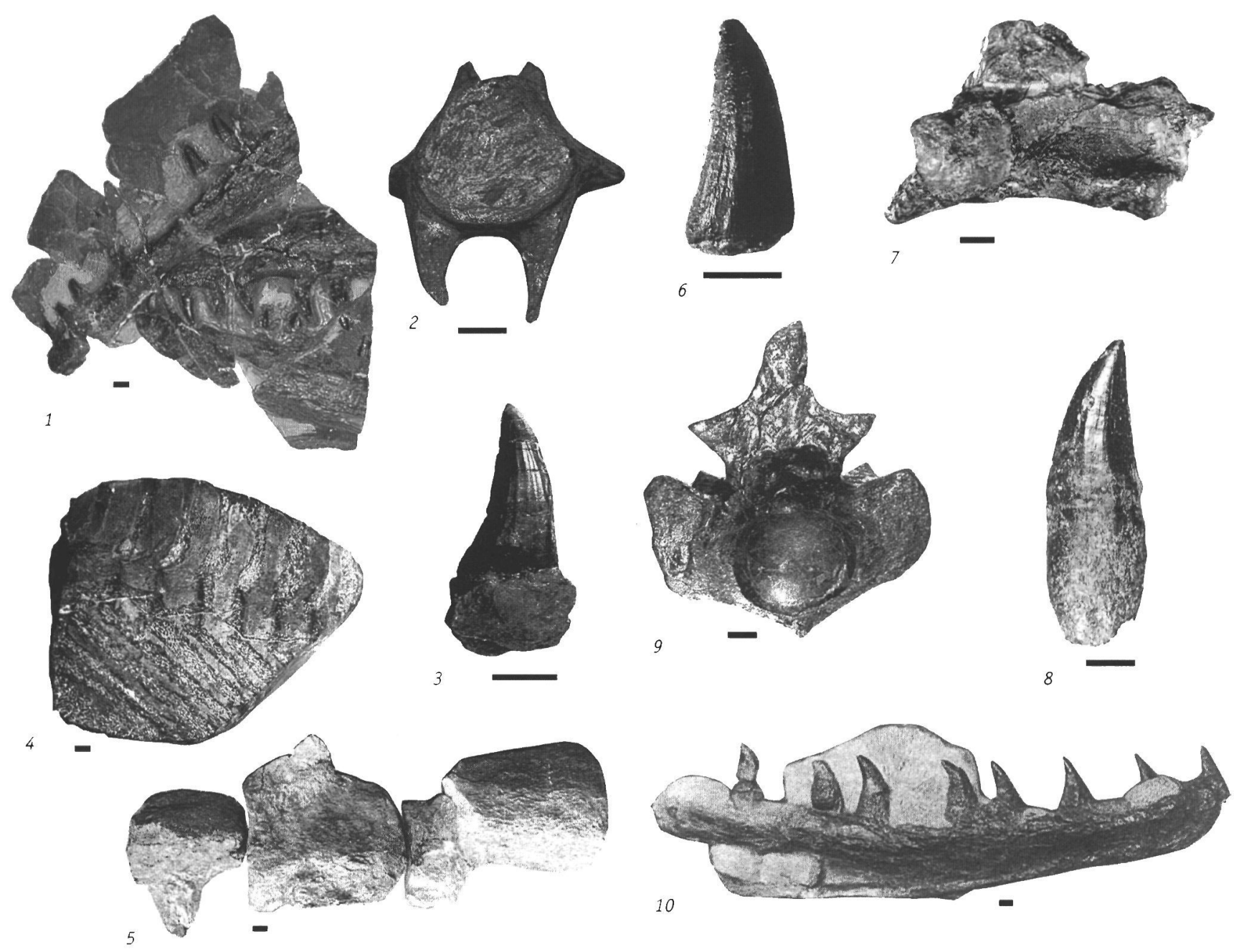

Fig. 3. 1 - Skull and lower jaw of Kourisodon sp. (Kanazawa specimen) from the upper Campanian Hiketa Formation at Kanewari, Sanuki City, Kagawa Prefecture (Tanimoto \& Kanazawa, 2001; Tanimoto et al., 2004). 2 - Distal view of the small mosasaurine caudal vertebra (Yokoi specimen) from the Maastrichtian Shintachi Formation of Hakotsukuri, Hannan City, Osaka Prefecture (Tanimoto et al., in press). 3 - Labial view of the small mosasaurine Kourisodon tooth (Minamino specimen) from the Maastrichtian Mutsuo Formation at Sobura, Kaizuka City, Osaka Prefecture (Tanimoto et al., 1998). 4 - Articulated distal portions of mosasaurine caudal vertebral column (Kikyo specimen) from the early Maastrichtian Shimonada Formation at Nadaokawa, Minamiawaji City, Hyogo Prefecture (Tanimoto \& Kikyo, 2001b). 5 -Semi-articulated lumbar vertebrae (Kishimoto specimen) from the lower Kita-ama Formation at Akeda, Sumoto City, Hyogo Prefecture (Tanimoto \& Kishimoto, 2002). 6 - Labial view of the slender tooth of Mosasaurus sp. B (Nunoya specimen) from the Maastrichtian Mutsuo Formation of Showaike, Sennan City, Osaka Prefecture (Tanimoto \& Nunoya, 2000, 2003). 7-9 - Mosasaurus sp. A (Dino Club in Kansai specimen) from the Maastrichtian Mutsuo Formation of Sobura, Kaizuka City, Osaka Prefecture (Tanimoto, 1993, 1997a; Tanimoto et al., 1994, 2004). 7 - Right lateral view of the basisphenoid. 8 - Labial view of the tooth. 9 - Posterior view of the cervical vertebra. 10 - Inner view of the left dentary bone of Mosasaurus sp. A (Yokoi specimen) which was recently found at Sobura (Tanimoto et al., 2005). It perhaps belongs to the same individual as the above-mentioned Dino Club in Kansai specimen. All scale bars are $10 \mathrm{~mm}$. 
skeleton was collected from the lower Maastrichtian (Tanimoto \& Kikyo, 2001a). Although mosasaurids from the Izumi Group generally are small- to medium-sized types, the presence of larger material from the lower Maastrichtian shows that larger animals occurred here as well.

\section{Acknowledgements}

First and foremost, I wish to thank the late Elizabeth L. Nicholls, who included reference to my Izumi Group mosasaur paper in her own description of Canadian Kourisodon. In addition, I thank Gorden L. Bell Jr. and Takehito Ikejiri for advice on Izumi Group mosasaurs, Michael Everhart, Eric W.A. Mulder and other all participants in the First Mosasaur Meeting (Maastricht, May 2004) for useful suggestions. I am grateful to Anne S. Schulp and John W.M. Jagt for editorial assistance. Tracy L. Ford and Jerry D. Harris kindly provided numerous mosasaur papers. Dr Y. Morozumi kindly permitted a use of the chart of biostratigraphic correlation of the Izumi Group. Last, but by no means least, I wish to thank the collectors of Izumi Group mosasaurs, in particular co-workers Masahiro Sato and Masahiko Takata, and my wife Yoshimi Tanimoto.

\section{References}

Geological Club of Kinki (Kinki Chigakukai), 1991. Izumi-Sanmyaku no Hakuakei Kasekishu (Cretaceous Fossils from the Izumi Mountains). Geological Club of Kinki: 93 pp.

Itihara, M., Ichikawa, K. \& Yamada, N., 1986. Geology of Kishiwada district; with geological map, 1:50,000. Geological Survey of Japan (Tokyo): 148 pp.

Iwaki, T. \& Maeda, H., 1989. Mudstone facies and the fossil molluscan assemblages of the Upper Cretaceous Izumi Group in the southeastern Awaji Island, southwest Japan. Research Report of Kochi University 38: 187-201.

Kawakami, T., Terui, K., Hasegawa, Y. \& Oishi, M., 1985. Upper Cretaceous mosasaurid teeth from the Kunitan Group, in the northeast of Kitakami Mountains, Japan. Bulletin of the Iwate Prefectural Museum 3: 133-142.

Morozumi, Y., 1985. Late Cretaceous (Campanian and Maastrichtian) ammonites from Awaji Island, southwest Japan. Bulletin of the 0saka Museum of Natural History 39: 1-58.

Nicholls, E. \& Meckert, D., 2002. Marine reptiles from the Nanaimo Group (Upper Cretaceous) of Vancouver Island. Canadian Journal of Earth Sciences 39: 1591-1603.

Obata, I., Hasegawa, Y. \& Otsuka, H., 1972. Preliminary report on the Cretaceous reptile fossils from Hokkaido. Memoirs of the National Science Museum 5: 213-222.

Ohara, M., 2004. Kyoryu Jidai in Wakayama (The age of dinosaurs in Wakayama). Wakayama Prefectural Museum of Natural History: 19 pp.

Sakurai, K., Chitoku, T. \& Shibuya, N., 1999. A new species of Mosasaurus (Reptilia, Mosasauridae) from Hobetsu, Hokkaido, Japan. The Bulletin of the Hobetsu Museum 15: 53-66.

Suzuki, S., 1985a. Upper Cretaceous mosasaur remains from southern part of central Hokkaido, Japan: a preliminary report. The Bulletin of the Hobetsu Museum 2: 31-42.
Suzuki, S., 1985b. A new species of Mosasaurus (Reptilia, Squamata) from the Upper Cretaceous Hakobuchi Group in the Central Hokkaido, Japan. Monograph of the Association for Geological Collaboration in Japan 30: 45-66.

Takata, M., 2004. Posterior dorsal vertebra of Mosasauridae found in the Izumi Mountain range, southwest Japan (Upper Cretaceous Maastrichtian). Bulletin of the Natural History Museum Kishiwada 1: 31-38.

Tanimoto, M., 1993. Mosasaurid fossils from Izumi Group (Maastrichtian) of 0saka Prefecture, West Japan. Abstracts, 142nd Regular Meeting of the Palaeontological Society of Japan: 41.

Tanimoto, M., 1997a. A tentative skeletal restoration of Mosasaurus cf. conodon (Reptilia, Squamata) from the Upper Cretaceous Izumi Group in Southwest Japan. Chigakukenkyu 46: 87-91.

Tanimoto, M., 1997b. Vertebrate fossils of the Upper Cretaceous Izumi Group, southwest Japan. Natural History Museum, Kishiwada City: 28 pp.

Tanimoto, M. \& Date, Y., 2000a. A small tooth of Mosasaurus from the Izumi Group (Upper Cretaceous Maastrichtian) of Kaizuka City, Osaka Prefecture, southwest Japan. Chigakukenkyu 48: 219-223.

Tanimoto, M. \& Date, Y., 2000b. The first find of a mosasarid phalange from the Upper Cretaceous Izumi Group, southwest Japan. Chigakukenkyu 48: 225-229.

Tanimoto, M., Kamei K. \& Miyamoto, J., 1995. 0sakahu Hannanshi Hakotsukuri no Izumisogun (koki hakuaki) yori sanshutushita sekitsuidobutsu kaseki tokuni mosasaurusurui ni tsuite (Vertebrate fossils of Izumi Group (Late Cretaceous) from Hakotsukuri, Hannan City, Osaka Prefecture - especially on mosasaurs). Journal of Fossil Research 27: 79.

Tanimoto, M. \& Kanazawa, Y., 2001. A mosasaurid fossil from the Upper Cretaceous Izumi Group (Upper Campanian) of Kagawa Prefecture, southwest Japan. Abstracts with Programs, 2001 Annual Meeting of the Palaeontological Society of Japan: 190.

Tanimoto, M., Kanazawa, Y. \& Sato, M., 2004. Kourisodon sp. (Mosasauridae) from the Upper Cretaceous Izumi Group (Upper Cretaceous Campanian) of Kanewari, Tawa, Sanuki City, Kagawa Prefecture, southwest Japan. Chigakukenkyu 52: 21-25.

Tanimoto, M. \& Kikyo, T., 2001a. Gillicus skeleton from the Upper Cretaceous Izumi Group (Lower Maastrichtian) of Yura-Cho, Sumoto City, Hyogo Prefecture, southwest Japan - the first find of a fossil of the family Ichthyodectidae in Japan. Chigakukenkyu 50: 41-43.

Tanimoto, M. \& Kikyo, T., 2001b. Articulated posterior caudal vertebrae of the Mosasauridae from the Upper Cretaceous Izumi Group (Lower Maastrichtian) of Nandan-Cho, Mihara-Gun, Hyogo Prefecture, southwest Japan. Chigakukenkyu 50: 161-165.

Tanimoto, M. \& Kishimoto, M., 2002. Big mosasaurid vertebrae from the Upper Cretaceous Izumi Group of Sumoto-City, Hyogo Prefecture, southwest Japan. Chigakukenkyu 51: 135-141.

Tanimoto, M. \& Miyamoto, J., 1996. A mosasaurid fossil from Nagata, Midorimati, Hyogo Prefecture, southwest Japan. Konseki 19: 41, 42.

Tanimoto, M. \& Nunoya, H., 2000. A mosasaurid tooth (Mosasaurus sp.) from the Upper Cretaceous Izumi Group of Showa-Ike, Sennan City, Osaka Prefecture, southwest Japan. Chigakukenkyu 49: 141-145.

Tanimoto, M. \& Nunoya, H., 2003. Reexamination of a mosasaurid tooth from the Upper Cretaceous (Maastrichtian) Izumi Group of Showa-Ike, Sennan City, 0saka Prefecture, southwest Japan. Chigakukenkyu 52: 101-105. 
Tanimoto, M., Sato, M. \& Takata, M., 1994. ?Mosasaurus sp. (Reptilia, Squamata) from the Upper Cretaceous Izumi Group in Osaka Prefecture, West Japan. Monograph of the Association for Geological Collaboration in Japan 43: 25-32.

Tanimoto, M., Sato, M. \& Takata, M., 2004. Reconsideration of a mosasaur lower jaw from Sobura, Kaizuka, Osaka Prefecture, southwest Japan. Chigakukenkyu 53: $99-103$.

Tanimoto, M., Shinzyo, T. \& Fujimoto, T., 2001. The first find of a mosasaurid tooth of the Upper Cretaceous Maastrichtian Izumi Group at Takinoike, Izumisano City, Osaka Prefecture, southwest Japan. Chigakukenkyu 50: 37-40.

Tanimoto, M. \& Takata, M., 2002. A juvenile (?) tooth of Chlamydoselachus sp. from the Upper Cretaceous Maastrichtian Izumi Group of Hashiramoto, Hashimoto City, Wakayama Prefecture, southwest Japan. Chigakukenkyu 51: 131-134.

Tanimoto, M., Tani, M. \& Minamino, M., 1998. Crocodilian-like teeth (? Mosasauridae) from the Izumi Group (Upper Cretaceous Maastrichtian) of Sobura, Kaizuka-city, 0saka Prefecture, southwest Japan. Chigakukenkyu 47: 91-95.

Tanimoto, M. \& Ueno, M., 2000. A small cervical vertebra of Mosasaurus sp. from the Upper Cretaceous Maastrichtian Izumi Group of Sobura, Kaizuka City, Osaka Prefecture, southwest Japan. Chigakukenkyu 49: 137-140.

Tanimoto, M. \& Yokoi, T., 2005. A find of the dentary bone of a mosasaurid from Sobura, Kaizuka, Osaka Pref., southwest Japan and its significance. Chigakukenkyu 53: 207-212.

Tanimoto, M., Yokoi, Takata M., in press. A find of the fossil of the Mosasaurinae (Reptilia) from Izumi Group of Hakotsukuri, Hannan, Osaka Prefecture, Southwest Japan. Chigakukenkyu 54.

Tsujino, Y., 2004. Lithofacies and faunal assemblages of the Upper Cretaceous Izumi Group in Kanewari area, Kagawa Prefecture, Japan. Bulletin of the Tokushima Prefectural Museum 14: 1-13. 